MIROSŁAWA NOWAK-DZIEMIANOWICZ

Wydział Historyczno-Pedagogiczny

Uniwersytet Opolski

Opole

Forum Pedagogiczne $2018 / 1$

Wpłynęło: 09.01.2018

Zatwierdzono do druku: 31.03 .2018 DOI: $10.21697 /$ fp.2018.1.12

\title{
KONCEPCJE UZNANIA W PERSPEKTYWIE PEDAGOGIKI OGÓLNEJ JAKO ALTERNATYWA WOBEC NEOLIBERALNEJ WIZJI WSPÓŁCZESNEGO ŚWIATA
}

\begin{abstract}
Streszczenie: Najważniejszym zadaniem, jakie stoi przed jednostką, jest praca nad własną tożsamością - jest ona jednocześnie przejawem samorealizacji i wolności współczesnego człowieka. Uznanie jako intersubiektywna relacja między ludźmi jest warunkiem naszej tożsamości. Wspólnota oparta na relacjach uznania to alternatywa dla nieoliberalnej koncepcji społecznej. Intersubiektywne relacje uznania tworzą się według Axela Honnetha w trzech sferach: $w$ sferze relacji intymnych (rodzina, bliscy ludzie, znaczący inni), w sferze prawa oraz w sferze gospodarki. Mamy więc trzy obszary, w których w relacji z innymi budujemy swoją tożsamość: rodzinę, prawo i gospodarkę wraz z rynkiem pracy. Społeczne relacje uznania mogą $\mathrm{w}$ moim przekonaniu stać się celem zmiany społecznej, będącej odpowiedzią na współczesny kryzys praktyk i legitymizacji.
\end{abstract}

Słowa kluczowe: uznanie, tożsamość, zmiana społeczna, relacje, rodzina, prawo, gospodarka, edukacja, neoliberalizm.

\section{Wprowadzenie}

Teoria uznania Axela Honnetha (2012) jest swoistą teorią zmiany społecznej, której motorem nie jest konflikt interesów, lecz konflikt moralny: konflikt uprawnień i reprezentacji. Zakłada ona, iż najważniejszym zadaniem, jakie stoi przed jednostką jest praca nad własną tożsamością - jest ona jednocześnie przejawem samorealizacji i wolności współczesnego człowieka. Teoria uznania, zaproponowana przez Axela Honnetha, nawiązująca do myśli Hegla, jest dzisiaj traktowana jako normatywna koncepcja będąca swoistą próbą autodefinicji nowoczesności

Relacje uznania traktować można jako podstawę wszelkiej intersubiektywności. Intersubiektywność oparta na relacjach uznania poprzedza jednostkową tożsamość. Rozwój koncepcji uznania opierać się więc musi na analizie i opisie istoty naszych kontaktów z innymi, istoty naszych społecznych więzi. 
Potrzeba uznania, deficyt uznania, odmowa uznania uruchamiają odmienne praktyki społeczne, w oparciu o towarzyszące im relacje społeczne ludzie konstruują odmiennie swoją tożsamość. Oparty na walce o uznanie konflikt moralny musi być przez pedagogikę ogólną: rozpoznany, opisany i zrozumiany na poziomie teoretycznym, na poziomie praktycznym powinien zmierzać do budowania pedagogicznej kultury uznania. Uznanie będące warunkiem każdej tożsamości powinniśmy w moim przekonaniu - włączyć dzisiaj w normatywny system celów wychowania/ edukacji. Zaprezentowany tekst będzie próbą uzasadnienia tego przekonania.

\section{Neoliberalne wizje współczesnego świata jako wyzwanie dla pedagogiki i pedagogów}

Teraźniejszość, nasza współczesność, określana bywa na bardzo wiele różnych sposobów. Ta wielość może być jednocześnie traktowana jako współczesności tej charakterystyka. Nie można bowiem w sposób jednoznaczny, z pełnym przekonaniem o własnej słuszności, sprowadzić jej do jakiejś jednej głównej cechy, do jakiejś jednej dominującej reprezentacji. Nazywana płynną lub drugą nowoczesnością (a także późną lub ponowoczesnością) doczekała się wielu diagnoz autorstwa zarówno antropologów, socjologów, filozofów społecznych, jak i pedagogów. W pierwszej części prezentowanego tekstu chciałabym skoncentrować się na krytyce jej ideologicznych podstaw, stojących za nimi uzasadnień i racji, a także roszczeń co do ich ważności, słuszności i prawdziwości.

W tym celu spróbuję syntetycznie przedstawić główne założenia liberalnej koncepcji, aby już na ich tle zarysować najczęstszą linię jej krytyki.

1. „Podstawą koncepcji liberalnej jest indywidualizm - uznanie jednostki za absolutny punkt odniesienia refleksji nad porządkiem społecznym. Uznanie to wyraża się poprzez kluczowe dla liberalizmu pojęcie wolności (autonomii) jednostki, które stanowi ostateczną rację uzasadniania wszystkich instytucji społeczeństwa liberalnego.

2. Liberalny aksjomat o nadrzędnej pozycji jednostki wymaga uzupełnienia. Ściśle mówiąc, mamy bowiem do czynienia nie tyle z jednostką, co z jednostkami. Społeczeństwo składa się z wielu jednostek i każda z nich musi być traktowana jako absolutny punkt odniesienia. Liberalna koncepcja społeczeństwa zakłada zatem uznanie pluralistycznego i policentrycznego charakteru porządku społecznego, przy czym każde z tych centrów ma w jego ramach dokładnie taką samą pozycję co i inne centra. Punktem wyjścia jest więc to, że wszystkie jednostki są równe w swej wolności. Zasada równej wolności stanowi w ramach tradycji liberalnej podstawowe kryterium oceny i legitymacji porządku społecznego. W oczach liberała porządek społeczny wtedy tylko zasługuje na miano słusznego i sprawiedliwego, gdy wolność każdej jednostki jest na równi szanowana, kiedy - innymi słowy - wszyscy mają równe prawa. 
3. Sama zasada równości praw jednak jeszcze nie wystarcza, aby powstał stabilny porządek społeczny. Widać to wyraźnie w modelu stanu naturalnego przedstawionym przez Hobbesa, w którym każda jednostka posiada równe nieograniczone prawo do wszystkiego, co w sposób konieczny prowadzi do stanu wojny wszystkich ze wszystkimi. Policentryczny ład społeczny może więc przyjąć trwałą postać tylko i wyłącznie w przypadku ograniczenia zakresu uprawnień jednostek poprzez przyznanie każdej z nich prawa do posiadania pewnej ograniczonej, ale bezwzględnie nienaruszalnej, przestrzeni prywatnej. Jak to ujął Locke, chodzi tu o prawo do życia, wolności i majątku - czyli o szeroko rozumiane prawo własności. Akcent położony na konieczność ochrony własności odsłania liberalne rozumienie wolności. Wolność postrzegana oczyma liberała wymaga przede wszystkim zagwarantowania pewnej fizycznej przestrzeni, w której jednostka będzie całkowicie swobodna w swoim działaniu i wolna od ingerencji innych. Jednostka ma prawo robić ze swoją własnością wszystko, co tylko chce. To, co do niej należy, może zmienić właściciela tylko i wyłącznie za jej wyraźną zgodą.

4. Ale zasada równej wolności nie sprowadza się jedynie do konieczności zagwarantowania każdemu jego własności prywatnej. Jednostka funkcjonuje również poza swoją sferę prywatną i nie naruszając prywatności innych, wchodzi z nimi w różnorakie relacje. Kolejnym aspektem liberalnego rozumienia wolności jest więc wolność działania w sferze publicznej. Jednostka realizuje siebie i swoją wolność, urzeczywistniając swoim działaniem to, co jest dla niej ważne - to, co rozumie jako swój istotny interes. Przekładając to na konkret: wolność działania oznacza tutaj swobodę poruszania się, wyboru zawodu, wolność słowa, wolność zrzeszania się. Prawo do swobodnego działania każdej jednostki pozostaje ograniczone - zgodnie z zasadą równej wolności - jedynie takim samym prawem pozostałych członków społeczeństwa. Przestrzeń publiczna, która powstaje w wyniku działań jednostek, to sfera wielorakich zrzeszeń i stowarzyszeń. U podstaw każdego takiego stowarzyszenia leży dobrowolna zgoda jego członków na przynależność do niego. Dla liberała jedyną dopuszczalną formą społecznych związków jest więc jakaś forma kontraktu, umowy na równi wolnych osób. Powstałe stowarzyszenia oparte są na wspólnocie interesu; nikt nie zwiąże się bowiem $\mathrm{z}$ innymi, o ile osobiście nie będzie tym zainteresowany.

5. Dopiero w tym miejscu pojawia się pytanie o wspólnotę polityczną, o państwo. Nie widać przy tym żadnych racji, aby w ramach postawy liberalnej państwo miało być potraktowane inaczej niż pozostałe formy stowarzyszeń. Jawi się więc ono w oczach liberała wyłącznie jako instrument, który ma służyć interesom jednostek, i różni się od innych stowarzyszeń w zasadzie tylko swoim zakresem. Podstawę tak pojmowanego państwa stanowi kontrakt rozumiany jako domniemana milcząca zgoda wszystkich obywateli - który 
konstytuuje władzę państwową jako strażnika nienaruszalności sfery prywatnej i gwaranta poszanowania równej wolności w sferze publicznej.

Liberalna koncepcja państwa jako zrzeszenia opartego na realizacji indywidualnych interesów, którą można by z tego względu nazwać koncepcją »ekonomiczną", nie pozwala odróżnić wspólnoty politycznej od innych form związków społecznych. Perspektywa polityczna w klasycznym sensie tego słowa, która wspólnocie państwowej przypisuje szczególną samoistną wartość, widząc w niej nie tylko dobro wspólne obywateli, ale również źródło ich tożsamości i sensu ich życia, jest niedostępna w podejściu »ekonomicznym", które dostrzega w państwie jedynie wartość użytkową, podporządkowaną indywidualnym celom i dążeniom" (Stawrowski 20o8, s. 45)

O sile liberalnej ideologii stanowi wartość jej ideologicznych podstaw, wspólnie, bezdyskusyjnie podzielana akceptacja dla takich wartości, jak wolność, równość i braterstwo. Wartości te są podstawą naszego myślenia o wspólnocie, są dla tej wspólnoty konstytutywne i jako takie w zasadzie nie podlegają podważeniu, krytyce ani sporom. Kto z nas, współczesnych, odważyłby się dzisiaj kwestionować aksjonormatywne podstawy ideologii liberalnej? Kto świadomie wystąpi przeciwko wolności, równości i sprawiedliwości? Uniwersalizm tych podstaw liberalnej ideologii jest z jednej strony jej wielką wartością, z drugiej zaś swoistą pułapką, często ograniczającą czy uniemożliwiającą jakąkolwiek krytykę tego sposobu myślenia o świecie społecznym. Liberalizm, jako nowy porządek społeczny, miał być projektem zakorzenionym w teorii społecznej zmiany, w teorii sprawiedliwości społecznej. Miał zapewnić niezależnym jednostkom podmiotowość, miał je prowadzić ku autonomii.

Krytyka liberalizmu, jaka stała się udziałem współczesnych badaczy, oparta jest według mnie na dostrzeżeniu swoistej pułapki, jaką za sobą on niesie. Oto zamiast autonomii jednostek mamy dzisiaj do czynienia z nowym ubezwłasnowolnieniem, z nowymi, nieistniejącymi dotąd zależnościami, z nowym rodzajem zniewolenia. Partykularność, związana z indywidualnymi dążeniami jednostek, kategoria interesu, poszerzona na wszystkie niemal obszary ludzkiego funkcjonowania skutkują poczuciem, że nic już nie robimy bez/interesownie, a to, co tworzy wspólnotę, jest chwiejne i stale zagrożone. Krytycy liberalizmu wskazują na jego sprzeczność z deklarowaną jako najlepsza, najsprawiedliwsza formą sprawowania władzy - z demokracją. Sprzeczność ta występuje pomiędzy prawami i wolnościami jednostki a żądaniem równości i społecznej partycypacji w polityce. I nawet propozycja Habermasa (2002, 2006), który twierdzi, iż sprzeczność ta znika wówczas, kiedy uświadomimy sobie, iż podstawowe prawa człowieka (główne założenia liberalizmu) i władza sprawowana przez lud (główna teza demokracji) są równie pierwotne, nie kończy tego sporu. Jest on stałą cechą demokratyczno-liberalnego państwa, o której C. Mouffe pisze tak: „Uwzględniwszy niemożliwość ostatecznego pogodzenia owych dwóch podstawowych logik liberalnej demokracji, należało oczekiwać takiego niepowodzenia. Nastała pora, aby demokratyczna teoria polityki wyrzekła się tego rodzaju sterylnych poszukiwań. Jedynie godząc się z jej 
paradoksalną naturą, będziemy mogli należycie rozumieć współczesną politykę demokracji: nie jako dążenie do niedającego się osiągnąć konsensu opartego na procedurach, lecz jako „agonistyczną konfrontację” niezgodnych interpretacji podstawowych liberalno-demokratycznych wartości” (Mouffe 2005, s. 28).

Sądzę, iż dostrzeżenie tej sprzeczności jest ważnym przejawem krytyki liberalizmu, który deklarował, że będzie projektem:

- teoretycznym, a nie ideologicznym, wykraczającym poza wszelkie dotychczasowe tradycje filozoficzne i towarzyszące im ograniczenia;

- uwalniającym ludzki rozum z ograniczeń lokalnych, partykularnych, etnocentrycznych, miał być projektem uniwersalnym. Według krytyków neoliberalizmu stał się on jedynie "niebezpiecznym złudzeniem” (MacIntyre 1996, s. 326).

Krytyka liberalizmu (Chmielewski 2009, 2010) oparta jest także na dostrzeżeniu, iż podstawowa grupa, która miała być dla tego porządku kluczowa, została zdominowana przez własnościowe stosunki produkcji i pracy. „Pozycja robotników, która miała być oparta na znaczeniu przypisanemu pracy, znacznie się obniżyła. Stało się to dzięki, czy też przez zaangażowanie ich przedstawicieli, skupionych w związkach zawodowych w walkę o sprawiedliwość społeczną, prowadzoną według narzuconych tym związkom zasad i ról adekwatnych do reguł demokracji parlamentarnej. Walka ta prowadzona jest w oparciu o zdefiniowaną przez ideologię liberalną zasadę poszanowania własności prywatnej, jej skutkiem jest sprowadzenie robotników do ich poprzedniej roli: do roli instrumentów gromadzenia kapitału. Liberalizm stał się ideologią polityczną elit. Elity kontrolują zarówno te procesy demokratyczne, które są odpowiedzialne za reprezentatywność wszelkiej władzy (zależne media, dopuszczanie lub niedopuszczanie do głosu przedstawicieli różnych niewygodnych, a przez to wykluczanych środowisk), jak i odpowiadają za rodzaj i treść debaty publicznej, w której promuje się raczej bierność niż aktywność i raczej utrudnia się niż ułatwia (lub zupełnie przysłania) rozumienie dokonujących się zmian i mechanizmów społecznych, na których zmiany te są oparte. Zwiększa się także coraz bardziej zależność elit politycznych - czy nawet osób do aktywności politycznej aspirujących od elit finansowych. Brak poparcia elit finansowych skutecznie wyklucza ludzi z realnego wpływu na podejmowane decyzje. Demokracja staje się kolejnym społecznym pozorem. Indywidualizm moralny, charakterystyczny dla ideologii liberalnej, prowadzi do osłabienia lub nawet zniszczenia więzi między ludźmi, więzi będących warunkiem uczestnictwa we wspólnocie politycznej, zorganizowanej i dążącej do jakiegoś wspólnie zdefiniowanego dobra. Prowadzi to do zastąpienia uniwersalnego znaczenia takich wartości, jak sprawiedliwość czy dobro takimi znaczeniami, które łączą pojęcie sprawiedliwości z użytecznością, ze sprawiedliwą umową społeczną, czy sprawiedliwością nabywania dóbr" (Nowak--Dziemianowicz 2016, s. 47).

Dostrzeżeniu tych sprzeczności towarzyszy przekonanie o zablokowaniu możliwości porozumienia się i komunikacji między spierającymi się stronami. 
Można dzisiaj wskazać na trzy charakterystyczne cechy współczesnego dyskursu zarówno w sferze publicznej, jak i aksjonormatywnej, które przesądzają o zupełnej niemożności dojścia w tym dyskursie do jakiegokolwiek porozumienia. „Pierwszą z nich jest zasadnicza nieprzystawalność czy nieadekwatność argumentów, jakimi posługują się strony tego dyskursu. Niewspółmierność argumentów, ich wzajemna nieprzekładalność uniemożliwia każdej ze stron ich akceptację, prowadzi ponadto do przejmowania władzy nad takim dyskursem emocjom, histeriom lub uprzedzeniom. Jeśli nie ma możliwości oparcia się w dyskursie na argumentach, gdyż pochodzą one z porządków, między którymi nie ma żadnego związku, wtedy do głosu muszą dojść i dochodzą argumenty oparte na emocjach, argumenty irracjonalne. Pojawia się krzyk, obraźliwe słowa, tworząc taki obraz wspólnoty, który nazwać można „epoką nowego barbarzyństwa” (MacIntyre 1996, s. 466).

Drugą cechą współczesnego dyskursu moralnego jest pozorna obiektywność każdej z uczestniczących w nim stron. Ta pozorna obiektywność oraz związana z nią bezosobowość i racjonalność mają sugerować, że istnieje jakaś ponadhistoryczna, ponadosobowa i niesubiektywna racja, i że jest to zawsze racja tej strony, która się do niej właśnie odwołuje. Takie odwołanie się do traktowanych jako uniwersalne racji staje się we współczesnym dyskursie moralnym jedynie kolejnym ideologicznym narzędziem dominacji.

Trzecią cechą tego moralnego dyskursu współczesności jest odwoływanie się w nim do różnych historycznych źródeł, co dowodzi jedynie niejednolitości i niejednoznaczności tego, co składa się na nasze dziedzictwo, co jest jego intelektualnym zapleczem czy też jego treścią. Proponowanym przez MacIntyre’a działaniem, które byłoby przezwyciężeniem powyższych ograniczeń, jest odrzucenie indywidualistycznego, emotywistycznego i racjonalistycznego dziedzictwa oświeceniowego jako warunku wstępnego zbudowania przez nas alternatywnych filozoficznych narracji o sobie samych (Nowak-Dziemianowicz 2016, s. 48).

Czy można ten konflikt, spór czy też krytykę jakoś przezwyciężyć? Sądzę, iż można dzisiaj znaleźć takie propozycje, wśród których na uwagę zasługuje C. Muffe, twierdząc: „Przedstawiam własne stanowisko, zgodnie z którym tego fundamentalnego konfliktu nie trzeba interpretować jako sprzeczności, lecz jako locus pewnego paradoksu. Twierdzę, że choć Schmitt słusznie podkreśla różnorodność form, jakie przyjmuje przeciwieństwo pomiędzy uniwersalistyczną logiką liberalizmu a demokratyczną koncepcją równości i potrzeby politycznego konstytuowania się demos, nie musimy się wcale wyrzekać którejś z tych dwu tradycji. Uznawszy, iż rezultatem ich połączenia jest paradoksalna konfiguracja, napięcie między obu logikami, można przedstawić w pozytywny sposób, bez uznania, że prowadzi do destrukcyjnej sprzeczności. Sugeruję, że akceptacja tego paradoksu istotnie pozwala zrozumieć, na czym polega siła liberalnej demokracji. Ustawiczne kwestionując stosunki inkluzji/ekskluzji stanowiące warunek niezbędnego dla funkcjonowania demokracji politycznej ukonstytuowania się «ludu», liberalny dyskurs uniwersalnych praw człowieka odgrywa istotną rolę w stałym podtrzymywaniu sprzeciwu 
w obrębie demokracji. Natomiast wytyczenie granic i ukonstytuowanie się demos, co stanowi niezbędny warunek korzystania z praw, możliwe jest jedynie dzięki demokratycznej logice ekwiwalencji” (Mouffe 2005, s. 29).

Kolejną propozycją przezwyciężenia poddawanych krytyce słabości liberalizmu mogą także stać się wywodzące się z filozofii Hegla, rozwijane przez Szkołę Frankfurcką, przede wszystkim przez Axela Honnetha, koncepcje uznania.

\section{Uznanie jako kategoria pojęciowa pedagogiki oraz jej etyczne zobowiązanie}

Uznanie jest zarówno społeczną potrzebą każdego z nas, jak i warunkiem naszej samorealizacji, naszego rozwoju, pracy nad własną tożsamością. Istniejemy społecznie, istniejmy z innymi tylko poprzez uznanie i dzięki niemu. Uznanie to ,ja” w oczach innych ludzi. To ich o mnie opinia, ich szacunek, ich akceptacja, ich demonstrowane, komunikowany respekt.

Uszanować, respektować, poważać, to znaczy obdarzyć kogoś uznaniem. Brak szacunku, brak akceptacji, brak poważania to odmowa uznania. Zaproponowana przez Axela Honnetha koncepcja uznania jest etycznym projektem społecznym, alternatywą dla neoliberalnego, współczesnego świata. Opiera się ona na przekonaniu, iż siłą, która odpowiada dzisiaj za postęp i rozwój społeczny, siłą, która prowadzi do społecznej zmiany, jest konflikt moralny. Jest to konflikt między przypisanymi jednostce wolnościami a możliwościami ich realizacji. Jest to także konflikt partycypacji i reprezentacji. W świecie dominacji rynku i królującego na nim pieniądza gwarantowana równość wszystkich obywateli bywa problematyczna, pozostaje często jedynie na płaszczyźnie deklaracji i naszych pobożnych życzeń.

Uznanie traktowane jest $\mathrm{w}$ tej koncepcji jako najpełniejszy przejaw społecznego charakteru naszego „bycia w świecie”. Pokazuje, iż bez drugiego człowieka nie istniejemy, nie możemy się rozwijać, realizować, normalnie funkcjonować. W każdym momencie naszego życia przyglądamy się w oczach innych ludzi, w oparciu o ich opinie budujemy poczucie własnej wartości, ich oczekiwania wyznaczają często ścieżki naszych decyzji. „Uznanie stanowi idealną relację interpersonalną opartą na wzajemności pomiędzy podmiotami, w której każdy z nich traktuje innego jako równego sobie i jednocześnie odrębnego. Ta relacja jest konstytutywna dla subiektywności stajemy się bowiem indywidualnymi podmiotami tylko wówczas, gdy uznajemy suwerenność innego podmiotu i sami jesteśmy uznani przez innych" (Honneth 2012, s. 25).

Honneth twierdzi, że dla zrozumienia procesów społecznych, takich jak rozwój czy zmiana niezbędne jest skupienie się na doświadczeniu jednostki, doświadczeniu widzianym $w$ historycznym planie, zakorzenionym w szerokim, kulturowym kontekście, jednakże zawsze indywidualnym, subiektywnym, aktualnie przeżywanym. Bardzo ważna jest dla tej teorii kategoria intersubiektywności. To dzięki niej i poprzez nią możliwa staje się nasza praca nad własną tożsamością. „Człowiek nie byłby pełnym człowiekiem w samotności. Aby być pełnym człowiekiem, musi on spotkać drugiego człowieka i musi wejść z nim w dialektyczne sprzężenia uznania 
i odmowy uznania, odmowy uznania i uznania. W wyniku dialektycznych sprzężeń powstaje wspólnota ludzka, rodzi się społeczeństwo, a w tym społeczeństwie rodzi się także ludzka osobowość" (Tischner 2011).

Intersubiektywne relacje uznania tworzą się według Honnetha w trzech sferach: w sferze relacji intymnych (rodzina, bliscy ludzie, znaczący inni), w sferze prawa oraz w sferze gospodarki. Mamy więc trzy obszary, w których w relacji z innymi budujemy swoją tożsamość dzięki obecności innego i poprzez nią, poprzez stosunek innego do nas, stosunek połączony z naszym stosunkiem do niego. Intersubiektywność relacji uznania to ich warunek konstytutywny. Staję się niezależnym podmiotem dzięki i poprzez to, że inny w relacji ze mną także staje się niezależnym podmiotem. Te intersubiektywne relacje mają miejsce $\mathrm{w}$ wymienionych trzech sferach uznania: w rodzinie i relacjach z bliskimi, w obszarze praw oraz w świecie rynku, gospodarki, produkcji i pracy. „Niezwykle ważne w teorii uznania Axela Honnetha jest przekonanie, iż nowoczesne społeczeństwo jest zróżnicowaną strukturą sfer uznania, którą tworzą społecznie ustanowione wzorce interakcji, w które wpisane są za każdym razem różne zasady związane z uznaniem. W systemie społecznym obok siebie występują trzy równorzędne obszary uznania: rodzina, prawo oraz gospodarka. Te trzy obszary tworzą instytucjonalne ramy uznania, trzy ważne podsystemy społeczne, których celem jest $\mathrm{z}$ jednej strony wytwarzanie tego, co podtrzymuje system, z drugiej zaś to, co w normatywnie uregulowany sposób pozwoli zaspokoić oczekiwania związane z uznaniem (Honneth 2012). W każdym z wymienionych obszarów człowiek funkcjonuje w oparciu o ogólnie akceptowane wartości, w sposób, który pozwala mu spełnić przydzielone mu zadania z zachowaniem możliwości uzyskania, specyficznego dla każdej ze sfer działania, przypisanej jej formy uznania. To właśnie uznanie, które wiąże się z każdym z wyżej wymienionych obszarów działania, zapewnia nam dzisiaj, w czasach gwałtownej zmiany rozwinięcie się pozytywnych form samoodniesienia, identyfikacji i samoświadomości. Instytucjonalny porządek trzech wyżej wymienionych obszarów uznania (rodziny, prawa i gospodarki) musi spełniać trzy bardzo ważne warunki: musi się on opierać na normach, opisujących powiązanie pełnionej faktycznie przez jednostkę roli społecznej z przypisanym roli tej uznaniem, powiązanie to musi charakteryzować się trwałością (nie może mieć ono charakteru jednorazowego lub okazjonalnego), powinno także być ono artykułowane społecznie za pomocą czytelnych symboli ogólnych (czyli powinno być zrozumiałe).

W pierwszym obszarze uznania - w sferze miłości - chodzi o taki rodzaj relacji między ludźmi, których podstawą są silne związki emocjonalne oraz takie, w których nieobecny jest ekonomiczny i stanowy (statusowy) przymus. „Na tej pierwszej płaszczyźnie wzajemnego uznania jednostka - zaznając ze strony otoczenia: troski, zaangażowania oraz bliskości emocjonalnej - powinna się nauczyć postrzegać sama siebie jako indywiduum o określonych, elementarnych potrzebach, indywiduum, które wszelako zdane jest - gdy chodzi o możliwość wykształcenia niezaburzonej relacji do samego siebie - na innych oraz ich uwagę" (Fraser i Honneth 2005, s. 153). 
Uznanie kształtuje się tutaj poprzez wiarę w siebie, poprzez elementarne zrozumienie własnych potrzeb. Dopiero wtedy, kiedy doświadczymy tej pierwszej, zakorzenionej w obszarze rodziny formy uznania, będziemy mogli dostrzec znaczenie także cudzej perspektywy. Dzięki zdolności do dostrzegania cudzej perspektywy stajemy się zdolni do partycypacji, zdobywamy kompetencje społeczne, obywatelskie.

Drugim obszarem uznania jest prawo. Nowoczesne prawo opiera się na obietnicy równości moralnej wszystkich członków społeczeństwa, zakłada wzajemność uznania, która jest symetryczna i egalitarna, nie dopuszcza więc żadnego zróżnicowania związanego na przykład z pozycją społeczną. W tej sferze pojawia się pozytywne samoodniesienie polegające na szacunku do samego siebie, który wynika z tego, że własne działania możemy rozumieć jako wyraz indywidualnej autonomii. Etyczna wartość uznania zawarta jest w tym obszarze w samorozumieniu wszystkich jednostek traktujących siebie jako podmioty prawne wyposażone w moralną władzę sądzenia (Honneth 2012). Tak więc, jak chce Honneth, w sferze prawa uznaniu podlega ogólnoludzki potencjał rozumności. W obszarze prawa kształtują się prawne relacje jednostki. Jest ona jednak inaczej spostrzegana, niż było to na przykład u Habermasa czy też u Marksa (czyli przedstawicieli wcześniejszych okresów Frankfurckiej Szkoły Krytycznej). Jednostka nie jest przez Honnetha spostrzegana przez pryzmat swoich partykularnych interesów ani zbiorowych, wspólnym głosem reprezentowanych roszczeń. Prawa jednostki to odzwierciedlenie „uogólnionych innych”. Jednostki w tym ujęciu nie są postrzegane przez pryzmat podmiotowych potrzeb, lecz właśnie jako „uogólnieni inni”, pozostający wobec siebie w symetrycznej, opartej na prawie zależności i wzajemnie za siebie odpowiedzialni. Ważne dla zrozumienia tej teorii wydaje się rozumienie prawa, które Honneth traktuje jako przejaw uniwersalistycznej etyki, wobec której wszyscy ludzie pozostają równi, tak samo zobowiązani i tak samo autonomiczni. „Prawnie zapośredniczone relacje uznania zakładają przyznanie jednostce statusu moralnie odpowiedzialnego podmiotu sprawczego i w ten sposób pozwalają jej na rozwinięcie poczucia szacunku dla samej siebie. Prawne formy uznania nie są jednak raz na zawsze dane, ale podlegają redefinicji w wyniku konfliktów społecznych, które prowadzą do coraz pełniejszego uznania indywidualnej autonomii jednostki, jej różnorodnych potencjałów i roszczeń, nieuwzględnianych przez wcześniejsze formy uznania. Za Georgem Meadem Honneth stwierdza, że czynnikiem napędzającym walkę o uznanie i kontestację istniejących relacji społecznych jest napięcie między «me» oraz «I», a więc napięcie między zinternalizowaną wolą ogólną a roszczeniami związanymi z indywiduacją, które musi doprowadzić do konfliktu moralnego pomiędzy podmiotem a jego otoczeniem społecznym. «I» może w pełni wyrazić się tylko wtedy, gdy spotka się z aprobatą ze strony «uogólnionego innego», który ucieleśnia społeczne normy zakodowane w prawie. A zatem to właśnie z poziomu niekontrolowanego «I» pochodzi impuls, który przyczynia się do redefinicji tych norm i rozszerzenia zapośredniczonych przez nie relacji uznania" (Bobako 2010, s. XXX). 
Trzecim obszarem uznania jest gospodarka. Uznanie nie ma tutaj charakteru uniwersalnego ani normatywnego. Zależy ono w tej sferze od jednostkowych zdolności, talentów czy też zasobów. W mieszczańsko-kapitalistycznych społeczeństwach normą, na podstawie której określa się stopień prawomocności oczekiwanego uznania, jest zasada efektywności. Przejście od feudalnego społeczeństwa, w którym uznanie zależne było od pozycji stanowej czy pochodzenia do społeczeństwa opartego na mieszczańskim porządku, umożliwiło związanie kategorii uznania z jednostkowymi osiągnięciami i zdolnościami. W społeczeństwie mieszczańskim zasada efektywności własnych działań staje się jedną z trzech głównych fundamentalnych norm w ramach samorozumienia społeczeństw nowoczesnych, obok praw człowieka oraz ważności jego potrzeb emocjonalnych. Ten trzeci obszar uznania charakteryzuje się nieredukowalnym konfliktem, gdyż zasada efektywności często legitymizuje nierówności społeczne oraz rozwarstwienie charakteryzujące udział poszczególnych osób w dobrach ekonomicznych. Konflikt dotyczy także wykładni zasad efektywności oraz interpretacji osiągnięć, za które każda osoba czy też grupa mogą uzyskać szacunek. Wraz z komplikowaniem się i rozwojem współczesnej ekonomii wzrasta poziom niejasności i związanej z nią niezgody w kwestii związku pomiędzy indywidualnymi dokonaniami a zaznanym uznaniem. Honneth dostrzegając sprzeczność i konflikt związany z różnym pojmowaniem ważności indywidualnych talentów, zdolności i możliwości dla wspólnoty i przez wspólnotę, zwraca uwagę na przestrzeń uniwersalnej solidarności między członkami jakiejś wspólnoty. Ta uniwersalna solidarność, przejawiająca się w zobiektywizowanej przestrzeni nowoczesnego podziału pracy, polega na tym, iż jednostka dokonując wkładu w życie wspólnoty, może domagać się uznania własnej partykularności. Niezwykle ważna jest tutaj symetria ludzkiej partykularności, przejawiająca się nie tylko w tolerancji, rozumianej jako otwarcie na różnicę, odmienność i inność, ale jako pełne zaangażowanie i troskę o partykularność innych. „Do pozytywnych form samoodniesienia - wiary w siebie oraz szacunku do siebie, uzyskiwanych dzięki uznaniu w sferze miłości oraz w sferze prawa - dochodzi zatem kolejny aspekt osobowości: dzięki doświadczeniu bycia uznanym za swoje indywidualne talenty i umiejętności powstaje praktyczne samoodniesienie, które polega na cenieniu siebie. Te trzy pozytywne rodzaje samoodniesienia pozwalają jednostce na postrzeganie siebie jako osoby o określonych potrzebach, jako osoby rozumnej oraz jako osoby wartościowej" (Honneth 2012).

Tak więc u podstaw każdej ze sfer uznania leży każdorazowo pewna szczególna zasada uznania, dzięki której ludzie mogą znaleźć: w pierwszym obszarze troskę i uwagę okazywane nienaruszalnej, cielesnej tożsamości każdego człowieka, w obszarze drugim - szacunek okazywany rozumności osobie obdarzonej kompetencją moralną, osobistą autonomią oraz uzasadnionymi roszczeniami co do ważności, prawomocności i legalności własnych zachowań i dążeń, w obszarze trzecim (w sferze działania rynkowego) - uznanie społecznie wartościowych cech i umiejętności. 
Tak rozumiane uznanie nie jest jednak raz na zawsze dane człowiekowi, nie jest niczym zagwarantowane. Jest możliwością, rodzajem intersubiektywności, projektem etycznym. Jest także często deficytem w naszych relacjach $z$ innymi. Międzyludzka przestrzeń uznania wykształca się w toku codziennej wymiany społecznej. Uznanie oznacza akt, w którym wyartykułowane zostaje to, że inna osoba ma wartość, jest wobec tego źródłem prawomocnych roszczeń. Trzy podstawowe formy uznania to: zaufanie do samego siebie, poczucie godności osobistej i poczucie własnej wartości. Strukturę uznania tworzą trzy obszary: rodzina, społeczeństwo obywatelskie i państwo. W tych strukturach uznanie realizuje się poprzez miłość, prawo i solidarność. Tym trzem formom uznania towarzyszą trzy rodzaje doświadczeń, które są przejawem odmowy uznania i które stanowią zagrożenie dla integralności ludzkiej tożsamości: przemoc fizyczna, pozbawienie praw i pogarda. Wszystkie te przejawy odmowy uznania oznaczają jednocześnie zerwanie intersubiektywnej wzajemności oraz zaburzenie społecznej więzi, w której konstytuuje się tożsamość. Przemoc narusza integralność fizyczną jednostki, pozbawienie praw odbiera jej szacunek, zaś pogarda skazuje na zamknięcie jej w doświadczeniu wstydu, co prowadzić może do utraty poczucia własnej wartości. Doświadczenie odmowy uznania jest punktem wyjścia, impulsem do walki o uznanie - zarówno jednostek, jak i grup społecznych. Walka ta wymaga zarówno rozumienia własnego doświadczenia we wszystkich trzech obszarach uznania, jak źródeł odmowy tego uznania oraz możliwości działania w celu redefinicji własnego położenia" (Nowak-Dziemianowicz 2016, s. 60-62).

W pierwszym obszarze uznania buduje się nasze poczucie bezpieczeństwa, nazywane często bezpieczeństwem ontologicznym. Bez niego niemożliwy jest harmonijny rozwój, niemożliwe jest dążenie do jakiejś spójności, względnej stałości naszego postępowania, naszego „bycia w świecie”. Bezpieczna, na początku nawet symbiotyczna i bezwarunkowo akceptująca relacja z bliskimi, ze „znaczącymi innymi”, staje się tutaj warunkiem relacji uznania. Nasza potrzeba uznania może być zaspokojona tylko wówczas, kiedy nasi najbliżsi obdarzą nas podstawowym zaufaniem, bezwarunkową akceptacją. Ta relacja stanowi także warunek naszych dojrzałych relacji z innymi, naszych więzi społecznych w przyszłości oraz naszej społecznej partycypacji.

W obszarze drugim buduje się nasza autonomia moralna. Wyposażeni w moralną władzę sądzenia, wydawania ocen, przyznajemy identyczne prawo innym wszystkim innym. Nie chodzi tutaj ani o siłę, ani dominację, interes czy społeczną pozycję. Jako równi wobec prawa wszyscy mamy taki sam głos - bez względu na to, w jakim miejscu struktury czy hierarchii społecznej jest on ulokowany, w jakim miejscu jesteśmy, z jakiego miejsca mówimy. To jest źródło naszego szacunku do siebie, a zarazem przejaw naszego szacunku do innych.

W obszarze trzecim powstają intersubiektywne relacje uznania oparte na naszej obecności w świecie pracy: gospodarki, produkcji, usług. I nie chodzi tutaj tylko o takie sytuacje, w których ludzie wchodzą w interakcje polegające na tym, 
że szanują się w sposób symetryczny, oparty na grupowo (wspólnotowo) akceptowanych normach i wartościach lub jako ci, którzy partycypują jednocześnie w swoich wzajemnych drogach życiowych. Symetryczny szacunek oznacza tutaj solidarność społeczną pomiędzy zindywidualizowanymi i autonomicznymi podmiotami. „Wzajemne poszanowanie oznacza tutaj, iż podmioty postrzegają siebie nawzajem w świetle wartości, dzięki którym cudze cechy i zdolności jawią się każdorazowo jako znaczące w kontekście wspólnej praxis. Tego rodzaju relacje można nazwać solidarnymi, ponieważ usposabiają one nie tylko do pasywnej tolerancji względem innych, ale i pobudzają do emocjonalnego uczestnictwa w indywidualnej odrębności innej osoby; jedynie bowiem w tej mierze, w jakiej jestem aktywnie zaangażowany w to, by mogło dojść do rozwoju charakteryzujących ją, nieposiadanych przeze mnie właściwości mogą się urzeczywistniać nasze wspólne cele" (Honneth 2012, s. 127).

Bezwarunkowa akceptacja, pełna moralna autonomia, związana z prawem do sądzenia i bycia sądzonym, oraz dostrzeżenie i docenienie wartości, talentów i możliwości u innych, dzięki którym możemy jako wspólnota realizować ważne dla nas cele (zarówno w wymiarze jednostkowym, jak i grupowym), to rezultaty intersubiektywnych relacji uznania. Oparte na nich społeczeństwo mogło by stać się wspólnotą ludzi bezpiecznych, godnych, szanujących siebie i innych, zdolnych do kooperacji i współpracy.

Jestem przekonana, iż propozycja Axela Honnetha, oparta na intersubiektywnej relacji uznania, może być alternatywą wobec pełnej sprzeczności liberalnej demokracji.

Mówiąc o intersubiektywności relacji uznania, Honneth podkreśla etyczny i polityczny potencjał tej idei oraz jej związek z walką o uznanie. Państwo i etyczność, na którym jest ono zbudowane, są według Honnetha szczególną formą intersubiektywności. Etyczność tworzy się poprzez intersubiektywne relacje między jednostkami, a nie poprzez wertykalne relacje, które tworzą one z państwem. Takie wertykalne relacje jednostka-państwo budują wspólnotę hierarchiczną, prowadzą do autokratyzmu, monarchizmu czy nawet do totalitaryzmu. Honneth próbuje więc stworzyć koncepcję państwa opartego o posttradycyjną, demokratyczną etyczność, dzięki której możliwe stanie się pogodzenie prawnie gwarantowanej autonomii oraz jednostkowej partykularności z wymogami życia społecznego, zbudowanego na wspólnie podzielanym systemie wartości. „Owa posttradycyjna, demokratyczna etyczność ma nie tylko zawierać intersubiektywne warunki dla indywidualnej samorealizacji, ale ma także opierać się na głębokiej, społecznej solidarności. Ma być więc formułą łączącą wymogi formalnej, uniwersalistycznej moralności z określoną koncepcją dobrego życia” (Bobako 2012, s. XXX).

Społeczne relacje uznania mogą w moim przekonaniu stać się celem zmiany społecznej, będącej odpowiedzią na współczesny kryzys praktyk i legitymizacji. Brak uznania, deficyt uznania, odmowa uznania stają się dzisiaj jednym z podstawowych problemów jednostki oraz wspólnoty. Pogarda, której doświadczamy 
wówczas, kiedy inni odmawiają nam uznania, prowadzić może nie tylko do osłabienia czy zerwania społecznych więzi. Może stać się ona początkiem destrukcji, niszczących działań, które inspirowane potrzebą odwetu skierowane będą przeciwko tym, którzy nam tego uznania odmówili. Żeby tego uniknąć, warto - jak sądzę - wpisać na stałe w nurt poszukiwań pedagogiki ogólnej kategorię uznania oraz budować z innymi pedagogiczną kulturę uznania. „Ta oparta na postulacie rozumienia prowadzącego do porozumienia kultura dotyczyłaby zarówno wiedzy o genezie, treści i zakresie norm i reguł społecznego życia, krytycznych umiejętności ich rozpoznawania oraz kompetencji do wspólnego konstruowania narracji naszej wspólnoty w oparciu o akceptowane przez siebie reguły oraz normy, będące częścią dobra wspólnego. Byłaby więc zdolnością do rozpoznania i rozumienia narracji wspólnoty, której jesteśmy częścią, z której się wywodzimy i która decyduje o naszej indywidualnej, jednostkowej tożsamości. Jednocześnie ta sama kultura uznania umożliwiałaby konstruowanie także biografii osobistej, opartej o własny plan biograficzny, tworzący otwartą strukturę procesową, zdolną do ciągłych przeobrażeń i rozwoju w oparciu o rozpoznane przez siebie wartości, potrzeby, pragnienia. Kultura uznania byłaby próbą przezwyciężenia dychotomii między tym, co indywidualne i społeczne, oraz tym, co konieczne, narzucone i stałe, a tym, co własne, konstruowane i zmienne. Byłaby także swoistym zobowiązaniem pedagogiki. Zobowiązaniem do budowania przestrzeni dla porozumienia. Pedagogiki traktowanej jako dyscyplina, na gruncie której możliwe stają się nie tylko diagnozy, pokazujące zarówno deficyt lub odmowę uznania, ale także walkę o to uznanie toczącą się w naszych wzajemnych relacjach. Zdolność i zobowiązanie do czynienia takich diagnoz to dla mnie pierwszy z wymogów składających się na kulturę uznania. Drugim, równie ważnym, byłby wymóg inicjowania w obszarze pedagogiki jako dyscypliny naukowej oraz jako praktyki społecznej takich badań oraz działań, które walkę o uznanie nie tylko rozumieją, potrafią opisać i zinterpretować. Myślę o takich edukacyjnych działaniach, które poprzez ich powszechność, masowość, szeroki zasięg i społeczne, podzielane poczucie ważności sprawią, że poszerzą się przestrzenie uznania, poszerzą się obszary, w których ludzie nie doświadczają już jego deficytu. Edukacja zarówno na poziomie poznawczym, jako wiedza umożliwiająca ludziom rozumienie tego, co $\mathrm{w}$ relacjach $\mathrm{z}$ innymi się $\mathrm{z}$ nimi samymi dzieje, a także jako praktyka społeczna, powinna stać się metodą, formą, treścią walki o uznanie. Budować relacje uznania można w każdym momencie i w każdym miejscu, w każdym środowisku wychowawczym, w każdym intencjonalnym i nieintencjonalnym działaniu wychowawczym. Można to robić we wszystkich przestrzeniach naszego wspólnotowego życia: w prywatnej przestrzeni małżeństwa i rodziny, związków koleżeńskich, przyjacielskich, sąsiedzkich, w przestrzeni publicznej, w polityce, w mediach, w każdym naszym społecznym zaangażowaniu.

Dostrzec drugiego, zrozumieć drugiego, mieć świadomość jego autonomicznych, moralnych praw oraz jego bezwarunkowej wartości dla wspólnoty, wartości opartej na jego rzeczywistych możliwościach, umiejętnościach, talentach, wartości 
nieprowadzącej do żadnych hierarchii, tylko dotyczącej każdego członka wspólnoty, bez względu na status, pochodzenie, zasoby materialne, to według mnie ważnie i niezwykle aktualne zadanie pedagogiki i edukacji. Na jego dostrzeżeniu, na jego rozumieniu i na jego podjęciu polega według mnie zaangażowanie tej dyscypliny, jej interwencyjny charakter. Pedagogiczna kultura uznania byłaby przejawem tego zaangażowania” (Nowak-Dziemianowicz 2016, s. 375).

\section{Zakończenie}

Prezentowany artykuł przedstawia alternatywę wobec liberalnej demokracji, dotkniętej kryzysem i sprzecznościami między jednostkowymi prawami a zasadą równości i sprawiedliwości społecznej. Koncepcja uznania, nawiązująca do myśli Hegla, rozwijana współcześnie przez Axela Honnetha, wydaje się być taką alternatywą. Intersubiektywne relacje uznania mogą współczesnym ludziom pomóc w łączeniu ważnych dla nich wartości: indywidualizmu oraz poczucia wspólnoty, tego, co moje, niepowtarzalne, $\mathrm{z}$ tym, co wspólne, w czym jestem i muszę być zadomowiona, jakoś zakorzeniona. Pedagogika, jako nauka o wychowaniu, które $\mathrm{w}$ najszerszym rozumieniu tego pojęcia jest wprowadzaniem drugiego w świat wartości, powinna rozwijać na swoim gruncie teorie uznania i zbudować $\mathrm{w}$ oparciu o nie pedagogiczną kulturę uznania. Istotą tej kultury byłoby rozumienie prowadzące do porozumienia. Tylko rozumiejąc siebie oraz wszelkich „innych”, znajdujących się wokół mnie, mogę obdarzyć ich uznaniem, a także poczuć się szanowanym i uznanym członkiem większej wspólnoty. Rozumienie prowadzące do porozumienia, to ważny postulat pedagogiki odpowiadającej na problemy współczesności, pedagogiki zaangażowanej.

\section{Bibliografia}

Bobako M. (2010). Demokracja wobec różnicy. Multikulturalizm i feminizm w perspektywie polityki uznania. Poznań: Wydawnictwo Poznańskie.

Bobako M. (2012). Zaklinanie nowoczesności. Axel Honneth i moralna gramatyka filozoficznych przemilczen. W: Honneth A., Walka o uznanie. Moralna gramatyka konfliktów społecznych. Kraków: Zakład Wydawniczy Nomos.

Chmielewski A. (1996). Wprowadzenie. Filozofia moralności Alasdaira Maclntyre’a. W: MacIntyre A. Dziedzictwo cnoty. Warszawa: Wydawnictwo Naukowe PWN. Chmielewski A. (2009). Polityka i etyka Alasdaira MacIntyre. W: MacIntyre A. Etyka i polityka. Warszawa: Wydawnictwo Naukowe PWN.

Chmielewski A. (2010). Dwa komunitaryzmy (Nowak W. M. „Spór o nowoczesność w pogladach Charlesa Taylora i Alasdaira Maclntyre'a. Analiza krytyczna", Rzeszów 2008). „Studia Philosophica Wratislaviensia”, z. 4. 
Fraser N., Honneth A. (2005). Redystrybucja czy uznanie? Debata polityczno-filozoficzna, Wrocław: Wydawnictwo Naukowe Dolnośląskiej Szkoły Wyższej Edukacji TWP.

Habermas J. (2002). Teoria działania komunikacyjnego. T. 2: Przyczynek do krytyki rozumu funkcjonalnego, tłum. A. M. Kaniowski. Warszawa: Wydawnictwo Naukowe PWN.

Habermas J. (2006). Działanie zorientowane na osiagnięcie porozumienia. W: Jasińska-Kania A. i in. (red.). Współczesne teorie socjologiczne. T. 2., Warszawa: Wydawnictwo Naukowe Scholar.

Honneth A. (2012). Walka o uznanie. Moralna gramatyka konfliktów społecznych. Kraków: Wydawnictwo Nomos.

MacIntyre A. (1996). Dziedzictwo cnoty, tłum. A. Chmielewski. Warszawa: Wydawnictwo Naukowe PWN.

Mouffe C. (2005). Paradoks demokracji. Wrocław: Wydawnictwo Naukowe Dolnośląskiej Szkoły Wyższej.

Nowak-Dziemianowicz M. (2016). Walka o uznanie w narracjach. Jednostka i wspólnota $w$ procesie poszukiwania tożsamości. Wrocław: Wydawnictwo Naukowe Dolnośląskiej Szkoły Wyższej.

Tischner J. (2011). Spór o istnienie człowieka. Kraków: Wydawnictwo Znak.

Stawrowski Z. (2006). Prawo naturalne a ład polityczny. Kraków, Warszawa: Instytut Myśli Józefa Tischnera, Instytut Studiów Politycznych PAN.

Stawrowski Z. (2017). Ośrodek Myśli Politycznej, dostępny na: http://omp.org.pl/ artykul.php?artykul=26 (otwarto: 27.11.2017).

\title{
CONCEPTS OF RECOGNITION IN THE PERSPECTIVE OF GENERAL PEDAGOGY AS AN ALTERNATIVE TO THE NEOLIBERAL VISION OF THE MODERN WORLD
}

\begin{abstract}
The most important task facing an individual is the work on their own identity - it is a manifestation of self-realization and freedom of a modern man. Recognition as an intersubjective relationship between people is a condition of our identity. A community based on recognition relationships is an alternative to a neo-liberal social concept. Intersubjective relationships of recognition are formed, according to Honneth, in three spheres: in the sphere of intimate relations (family, people that are close to us, significant others), in the sphere of law and in the sphere of economy. We have three areas then, in which, in relations with others, we build our identity: family, law and economy with labor market. In my opinion, social relations of recognition may become the goal of social change, which is a response to the contemporary crisis of practice and legitimacy.
\end{abstract}

Key words: recognition, identity, social change, relationships, family, law, economy, education, neoliberalism. 
Mirosława Nowak-Dziemianowicz - prof. dr hab. Studiowała na Uniwersytecie Wrocławskim pedagogikę i psychologię. Tam też uzyskała naukowe stopnie doktora i doktora habilitowanego. Ostatnie 20 lat współtworzyła Dolnośląską Szkołę Wyższą, gdzie pełniła funkcję dyrektora Instytutu Pedagogiki, a także dziekana Wydziału Nauk Pedagogicznych. Była wiceprzewodniczącą Komisji Edukacji w Radzie Głównej Szkolnictwa Wyższego, ekspertką MNiSZW ds. Krajowych Ram Kwalifikacji. Obecnie pracuje na Uniwersytecie Opolskim, gdzie pełni funkcję kierownika Katedry Teoretycznych Podstaw Edukacji i Wychowania. Najważniejsze publikacje: Oblicza nauczyciela. Oblicza szkoły (Toruń 2001), Doświadczenia rodzinne w narracjach. Interpretacje sensów i znaczeń (Wrocław 2002), Edukacja i wychowanie w dyskursie nauki i codzienności (Kraków 2014), Oblicza edukacji. Między pozorami a refleksyjna zmiana (Wrocław 2014), Walka o uznanie w narracjach. Jednostka i wspólnota w procesie poszukiwania tożsamości (Wrocław 2016). Główne obszary zainteresowań: radykalna krytyka współczesnej szkoły jako instytucji opresyjnej, pełnej pozoru i rozwojowych blokad oraz relacje między ludźmi, związki intymne, małżeństwo, rodzina, socjalizacja i wychowanie, tożsamość i zmiana. Orientacja metodologiczna: badania narracyjne, biograficzne oraz krytyczna analiza dyskursu. Adres e-mailowy: mdziemianowicz@uni.opole.pl. 